\title{
CLOUD COMPUTING: SEARCHING ITS USE IN PUBLIC MANAGEMENT ENVIRONMENTS
}

\section{Jairo Simião Dornelas}

Universidade Federal de Pernambuco, Brazil.

\section{Kassia Roberta Rodrigues de Souza}

Universidade Federal de Pernambuco, Brazil.

Seu Celé Restaurantes

Américo Nobre Amorim

Escribo

\begin{abstract}
The research investigated the perception about cloud computing (CC) in public management environments. After, from the perspective of information technology (IT) people on those organizations, it has raised views on how IT in the cloud is seen as a solution for governmentlevel service delivery. Then, managers of the top public management of two cities, sought aspects of feasibility, timeliness, necessity and actuality of the $\mathrm{CC}$, for the provision of digital services. Listening revealed $\mathrm{CN}$ is known, although misunderstood and will only be effective when the process and community service dimensions are delineated by the municipal management (modeling and implementation). Nevertheless, it was realized that the technology will be absorbed by public information technology and will replace the traditional one-way service delivery, favoring the increase of computational intelligence distributed in social scale and the inclusive participation of the population in the management of cities.
\end{abstract}

Keywords: Cloud Computing, Virtualization, e-gov aspects

Manuscript first received/Recebido em: 2017/Ago/22 Manuscript accepted/Aprovado em: 2017/Sep/04

Address for correspondence / Endereço para correspondência:

Jairo Simião Dornelas, Universidade Federal de Pernambuco. E-mail: jairo@ufpe.br

Kassia Roberta Rodrigues de Souza, Universidade Federal de Pernambuco; Seu Celé Restaurantes

E-mail: kassinharoberta@gmail.com

Américo Nobre Amorim, Escribo, Pernambuco, Brazil. E-mail: americo@escribo.com

The research was supported by CNPQ - Edital Universal 2013 and the Federal University of Pernambuco.

Published by/ Publicado por: TECSI FEA USP - 2017 All rights reserved. 


\section{INTRODUCTION}

Cloud computing presents itself as a trend in the modern and continuous evolution of enterprise information technology (VERAS, 2012). In this technological modality, data scattered on remote storage servers, peculiar data centers (data centers), provide users with the sensation of local storage, with quality and guarantee of access and are incorporated into the business repositories, which were included in the company architecture.

Therefore, considering the directions of the information and communication technology (ICT) market, companies consider using the facilities of this type of processing to support new transactions, raising the need to contemplate organizational issues, concerns about modeling and The procedural rules for this activity (GEORGES, 2010).

However, it is clear that if we rise to the position of business strategy, not only benefits will be associated with this technological innovation.

In fact, in the wake of this almost imperative to have and be in the cloud, information and business risks increase, data security gaps emerge, and new and more sophisticated service levels are evoked via new cryptographic protection applications.

What is certain in these times of constant modernity and ever-faster and more planned obsolescence is that the breakthrough of cloud computing affects society, organization, and individual, making the unimaginable nettop believable (DENNIS, 2003), antagonizing the certainty of the locality, projecting, as it were to study, latent signals of computational black hole and requiring intense investigation in the business field to admit the experience of the institutions in the century XXI (PERES, 2008).

This study focuses on this perspective, which is to present, discuss, develop and project this new life-span of organizations, including the public, under the mantle of the aSa service, an apparent technological panacea of the new millennium.

To that ind., he went to the field in order to rescue as top managers of public companies and also their directors of information technology environments, they are receiving this new cycle, the aaS cycle, and what adaptations can be projected in the vision Of these same leaders as to the experience of the managerial administration in the public scope in this new paradigm. A posteriori, still in the limbo of the tapping, due to reach spaces that were consecrated as of modernity in the treatment of the public thing with ruptures of use of TIC, tried to evaluate how receptivity of this new paradigm of the computation in the conduction of these same businesses like public actions in citizen and democratic bias.

The scripting for such a plot suggests assembly in parts. The first contemplated this introduction, in which shed light on the theme and briefly located the universe of listening. The other sections will deal with the context of calculation and will include the useful literary concepts to the development of field procedures - collection and analysis - that will outline the way in which the results found will be brought to the stage. As a conclusion, a short final section will speculate on how the results found here may favor a greater empowerment of citizens who are beneficiaries of public management actions. 


\section{CONTEXT OF THE RESEARCH}

Organizations have undergone profound changes in recent decades. In this rhythm, as in a continuous motorcycle, technological change accelerates procedural change, which in turn requires new technological artifacts, in an odd cycle (DAFT, 2008).

Given the increasing involvement in the process world, ICT does not stop evolving and bringing changes to the organizational scope CARR, 2004). The constant innovations resulting from ICT are related to the reconfiguration of relationships, the requalification of people in different ways and the constant rethinking of business processes in search of efficiency (UNDERDAHL, 2008).

Cloud computing shows itself as one of these evolutions and brings with it undeniable contribution to the dissemination and accessibility of information, provoking changes in individual, organizational and social perspective (VERAS, 2012).

\subsection{Scenario}

The speed of production of new software suites in new architectures and computing platforms drives enterprises to cope with events such as portability, mobility and flexibility, and this scalability projects that people at a frenetic pace need information at the same pace, no matter where, it does not matter when, no matter where they come from (STAIR; REYNOLDS, 2011).

In this meeting of wishes, companies and people want immediate access to information and require the necessary information to be available at the right time, accessible on demand and available in a flexible, agile and always available computing architecture (LAUDON; LAUDON, 2011) which appears to be the supply of cloud computing.

In simpler terms, cloud computing initially provides services that are required in standard forms and are based on established administrative practices. Despite being coupled to an internal computing architecture, cloud computing provides modernity, uptime availability, and certainly market tuning (VOUK, 2008). However, although this is quicker, this scope is much more in keeping with the technical information technology and its virtualized processes (OVERBY, 2008).

In the scope of its usual implementation, cloud computing technology requires little more than a network connection and good process architecture, with well-defined business rules, to cover the events and planned activities (DIKAIAKOS et al, 2009). Nevertheless, it is questionable whether the organizations that use (or claim to use) this computational modality in their deal, are procedurally prepared to adopt the kind of service that the cloud offers. Without skepticism, we anticipate problems if the company is not fast or follow standards (DIKAIAKOS et al., 2009). In addition, there are also guidelines that mitigate risks and insecurity due to lack of data and not a glimpse of exact security mechanisms. 


\subsection{Problematic}

Cloud computing is a concrete example of the evolving evolution of the organizational routine generated by ICT (VERAS, 2012). Therefore, in view of the phenomenon of cloud computing, it is necessary to take stock of the understanding of cloud computing in management environments, at a preliminary level, trying to assess the impact of the possible implementation of this kind of cloud computing. Service in a public organization that performs with traditional computing.

At first, one imagines that processes, people, and the management dynamics and routines themselves will be affected. In the second instance, after locating which routines are affected in the organizational set, in a typically administrative view, it will be sought to ascertain the effect that this same service can cause, at least potentially, in the conceptions of provision of services in public agencies, expecting to affect the citizens' leadership.

Thus, the guiding question is to determine the main directions associated to the use of cloud computing in entities - companies and public agencies - that consider this variant as a computing platform to provide services to the community.

The initial survey in the field, with ICT analysts of the organizations that would be visited, was anchored in the application of a preliminary questionnaire, by electronic means, and aimed at the calculation on affectations of the modality in cloud as a platform of routine computation in elements and functional processes.

Subsequently, these perceptions served as a basis for deepening interviews with leaders (senior managers and ICT directors) of public agencies selected for convenience and ease of access, in the cities of Curitiba and Porto Alegre, places considered as avant-garde icons in social computing.

The research is justified by anticipating a certain gap in this area of studies in public organizations, namely the adequacy of operational, managerial and strategic processes to the cloud computing technology, which advances rapidly on the organizational scope. It also attempts to base knowledge on the aaS options, increasingly present in organizational rules, reviewing aspecto that have not been explored in the literature, and bringing the strength of decanted decision-making satisfaction and optimization to the unexplored cloud computing.

The study also denotes some pessimistic focus, since there are, of course, a set of changes that affect the stable processes of organizations, their structures, their rules and their experience, causing them some discomfort. Thus, the field assessment highlighted non uphanistics foci tied to the new computational routine, since does not always every technology improves the performance of an organization (CARR, 2004).

\section{BRIEF LITERATURE VISIT}

The beginning of the 21 st century witnessed the proliferation of the virtual term, thanks to the advance of computer science and technology as a whole. Virtual, according to Lèvy (2010) expresses the notion of force and power. Cano, Becker \& Freitas (2004) already affirmed that the virtual is what exists potentially in the real. Thus, within organizations, the term is linked to the virtual environment and substantially alters social, economic and personal relationships. 


\subsection{Virtuality}

The virtuality has importante characteristics, among which stand out the detachment of the here and now and the deterritorialization through the interactions by electronic means (WIGAND 1997). In order to understand the new forms of organization, it is necessary to follow the advance of the virtual in organizations, processes, operations and relations.

Norton (1997) notes that the concept of virtual organizations covers a set of flexible working practices facilitated by new ICTs. Such arrangements come to be seen as a network of resources that are assembled or disassembled according to their objectives, regardless of physical location (SILVEIRA, 2005). These arrangements emerge with impetus: continuous change, flexibility and the intensive use of ICT (AMORIM, 2007).

The greatest focus of this virtual action, which is set in the transition from a physical process to a virtual process, through the adoption or use of an ICT, is called process virtualization (OVERBY, 2008), that generates virtual processes. Such processes can be identified as the source of the inherent competencies of this new company and its importance is focused on the associated competitive values, such as increasing flexibility and the company's continuous capacity to adjust; The improvement of the dynamics of the company and the reduction of coordination and transaction costs in the operation of the company, as well as the definition and adjustments of strategies (WESKE, 2007).

For the public sector, this importance is mainly focused on increasing the effectiveness of services provided to the population, through the restructuring of the organization and the crossfunctional processes (PEREIRA, 1997; GULLEDGE JR \& SOMMER, 2002; BALDAN et al., 2009), especially in areas related to the citizen's well-being, such as health, education and transportation, which have an impact on the quality of life (KONTZER, 2010).

\subsection{Process Virtualization}

The perspective of relating ICT capabilities and process requirements is based on the theoretical arrangement called process virtualization theory (OVERBY, 2008; 2012), which had also been raised as an essential focus in the transition from physical to virtual processes. In fact, through the possibilities of transformation that ICT have, it is seen that process virtualization represents a technological consolidation that provides organizations with increased efficiency, more flexibility and greater effectiveness, in order to accelerate the achievement of the desired objectives (KONTZER, 2010).

In implementing this idea, processes are organized in virtual environments and there is a reduction of physical facilities, minimizing both public displacement and the need for intermediaries for storage and / or provision of information in order to obtain products or services (AGNES, 2007).

With naturalness, Overby \& Konsynski (2012) report that some processes are more likely to be conducted virtually in an organizational environment than others. This seemingly obvious conjecture creates functional driving forms that can include both the virtualization of ICT infrastructure and the virtualization of business processes. 
In this sense, process virtualization theory explains that processes at the level of interaction between people and objects have requirements (sensory and relationship) that can make them more or less likely to become virtual at the level of synchronism and control. This propensity would also be tied to the capabilities of representation, reach and monitoring embedded in ICTs that support the predicted interactions (OVERBY \& KONSYNSKI, 2012).

Thus, the symbiosis between a technology's capacity in terms of its elements and the welldefined existence of virtualization requirements directly and ostensibly influence the propensity to make a virtual process (OVERBY, 2012).

\subsection{Cloud computing}

The cloud computing technology has emerged as a new computing concept in which ICT services are provided in the sense of their utility by third parties, and by which users have transformed their infrastructure in a targeted approach to service (KARTHIKEYAN \& SUKANESH, 2012).

This concept is based on the sharing of computational tools, ranging from simple e-mail to high-capacity virtual servers (LUCAS, 2009), that is, users share resources, using them when needed, and this significantly reduces costs for all involved.

Several authors have discussed the concept of cloud computing as well as its utility within the corporate environment:

- Vouk (2008, p. 35) converged this definition to "a way of using ICT elements through an end user oriented architecture";

- Choi (2009) characterized cloud computing as a model to support data processing;

- Jain e Bhardwaj (2010, p. 8) Claim that cloud computing has evolved in the organizational context that defines it as "a type of service; a business model ".

This last premise is also defended by Veras (2012), which also ratifies an independence of execution for the functional areas and, consequently, a greater flexibility of performance in the management of the organization's business.

In general, five characteristics related to the phenomenon of cloud computing are listed, namely: 
Table 1. Characteristics attributed to the phenomenon of cloud computing.

\begin{tabular}{ll}
\hline On-demand service & Only when there is need of use connects to the service \\
\hline Broad network access & There is always a guarantee of availability of access \\
\hline Resource Pooling & A resource pool is dynamically mounted and made available \\
\hline Fast elasticity & When it needs new features they are quickly incorporated \\
\hline Measured service & There is charging per use and not fixed cost
\end{tabular}

Source: adapted from Buyya et al. (2011).

Under the mantle of the general characteristics and definitions obtained so far, two ways of implementing cloud computing are seen: according to the location and according to the types of services offered.

In this understanding, the first classification is based on the location of the infrastructure and refers to the Dillon et al. (2010) e Rawtani (2012), subdividing the cloud deployment models into: private cloud, public cloud, community cloud, and hybrid cloud model.

However, the most usual classification is that which associates cloud computing with the service provided (VOUK, 2008). As a rule, the activity pool associated with the service is centered around a data center (VERAS, 2012). This use has led to the emergence of the concept of as a service (aaS), which establishes itself as the typological definer of the use of cloud computing.

From this perspective, it is possible to construct a defining role for cloud computing services in the 11 categories listed in Table 2 (BUYYA ET AL., (2008); CHOI (2009); BHARDWAJ (2010); JAIN \& BHARDWAJ (2010); MARCON JÚNIOR ET AL. (2010); MARTINEZ (2010); NOOR ET AL., (2010); KARTHIKEYAN \& SUKANESH (2012)): 
Table 2. Types of cloud services.

\begin{tabular}{ll}
\hline Kind (as a service) & \multicolumn{1}{c}{ Service Definition } \\
\hline Data base & $\begin{array}{l}\text { Remote data management as a rule in standardized and multidimensional } \\
\text { databases }\end{array}$ \\
\hline Governance & $\begin{array}{l}\text { Management and monitoring of resources and virtualization via the Internet, } \\
\text { based on predefined policies }\end{array}$ \\
\hline Infrastructure & $\begin{array}{l}\text { Ensures provision of IT infrastructure to provide connectivity to physical } \\
\text { infrastructure and logic }\end{array}$ \\
\hline Information & $\begin{array}{l}\text { It aims to consume remotely hosted information as well as its integration via } \\
\text { software }\end{array}$ \\
\hline Integration & Provides "Enterprise Application Integration" \\
\hline Plataform & It is based on providing access to remote servers for application development \\
\hline Process & $\begin{array}{l}\text { Allows creation of business processes, interacting with a sequence of business } \\
\text { processes }\end{array}$ \\
\hline Security & $\begin{array}{l}\text { Imposes logical security services applied to navigation and vulnerability } \\
\text { control }\end{array}$ \\
\hline Test & $\begin{array}{l}\text { Provides environment for testing cloud applications, websites and remote } \\
\text { applications }\end{array}$ \\
\hline Storage & Provides storage within a data center \\
\hline Source Conse &
\end{tabular}

Source: Compiled from the various authors cited in the last paragraph.

Completely, Dillon et al. (2010) that the challenges to cloud computing in organizations refer to issues related to: security, performance, availability, difficulty integrating with legacy technology, poor ability to customize the service, concerns about the real cost of services offered in Cloud, difficulty in turning to the old ICT structure, if desired, and few suppliers.

In this respect, the government tends to benefit from the technology in question, especially as regards support to essential processes such as: transparency, inclusion, democratization and universalization of access and use (SELAMAT et al., 2006). 


\subsection{E-Gov}

The term e-gov refers to the use of ICT to provide services to citizens, as well as to facilitate the review and integration of processes, to improve the effectiveness of public administration and to create mechanisms of digital relations with the citizen (LAIA et al., 2011).

E-gov offers the citizen a more flexible format in the provision of services and, in addition, stimulates democratic functions and processes that can expand the role of the public sphere, such as participation, transparency, openness, decentralization, transference and horizontalization of power, representativeness, Control over public agents and social inclusion (GARCIA; POMAR \& HOESCHL, 2004; LÖFSTEDT, 2005).

Sanchez (2003) presents three main fields for e-gov, which generally result in the provision of services involving ICT, namely: citizen service (e-administration); Streamlining internal processes and public policy-making (e-governance); And promotion of the extension of democratic processes (e-democracy).

Thanks to its adaptation to the evolution of ICT, e-gov is presented as one of the most important solutions in the new millennium and around the world many governments have developed policies to implement it, in addition to expressing their intention and commitment to programs reform and modernization of public (BARBOSA; FARIA \& PINTO, 2004).

This posture defines and guides the new standards of efficiency, effectiveness and sustainability of the public administration, to ensure, through the management of technological resources, to achieve strategic goals and objectives of the government (BARBOSA; FARIA \& PINTO, 2004). In them, it is estimated, there is room for the glimpse of cloud computing and impacts that their uses can entail.

\section{METHODOLOGICAL PROCEDURES}

The research had a mixed character with quantitative and qualitative variants and sought to capture profiles of use, packaging in processes and understanding of specialists and users on the feasibility and strength of the technology employed.

In spite of these basic propositions for conduction, the content of the calculation and the property for work, the study looked forward to confirm in its survey parameters and standards identifiable in the literature and its transposition to the field practice, something quite quoted by the acronym aaS in several forums of disclosure.

Regularly this proposal can be framed as adhering to the survey strategy. From this perspective, the research worked with few standardized questionnaires to collect regular information with ICT analysts from the organizations that would be visited, and used the collection mechanisms comparable to the interviews, based on survey interviews, to determine the perception of Impacts of the offer of services present in the idea of cloud computing and its eventual adoption as a service platform, especially in the host of public agencies of the cities chosen for the visits. 
Of course, the implementation effort required negotiations for field incursions in the 2nd stage - linked to the collection of the questionnaires. The questionnaire copies were sent by email to the professionals, identified in a survey of the functional staff of municipal IT management entities in Curitiba and Porto Alegre. A total of 128 questionnaires were sent, but when the number of 100 responses was obtained after more than 30 days of waiting, this stage was closed. A priori, the public scrutinized stated whether or not it used cloud computing in its functional routine. For this item there was no check of the veracity of the answer.

The option of interviewing, with privileged actors from the public institutions of Curitiba and Porto Alegre, was taken for reasons that surround the common sense that these capitals in Brazil are the ones that obtain the best performance in the administration of public management with technological bases (E-gov) (WARSCHAUER, 2006). It was considered essential to hear these more experienced users about the future effects and adaptations to the use of technology in public organizations for their effect on processes, projects and people.

The selection of elements to assemble the script of the interviews that was taken to the polls with public entities, was purposely destined to touch elements closer to the social fact that the cloud computing entails.

Data analysis covered the two sets of evidence collected. The most formalized part sought to frame, processes, services and strategies vis-à-vis the options of services found, demanded or projected. To achieve this, we used simple descriptive statistics. On the other hand, the techniques of content analysis were used on the tapping, as a way to elucidate emerging categories about the destination of use of cloud computing. The research design reported in this subsection is shown in figure 1.

Figure 1. Research design.

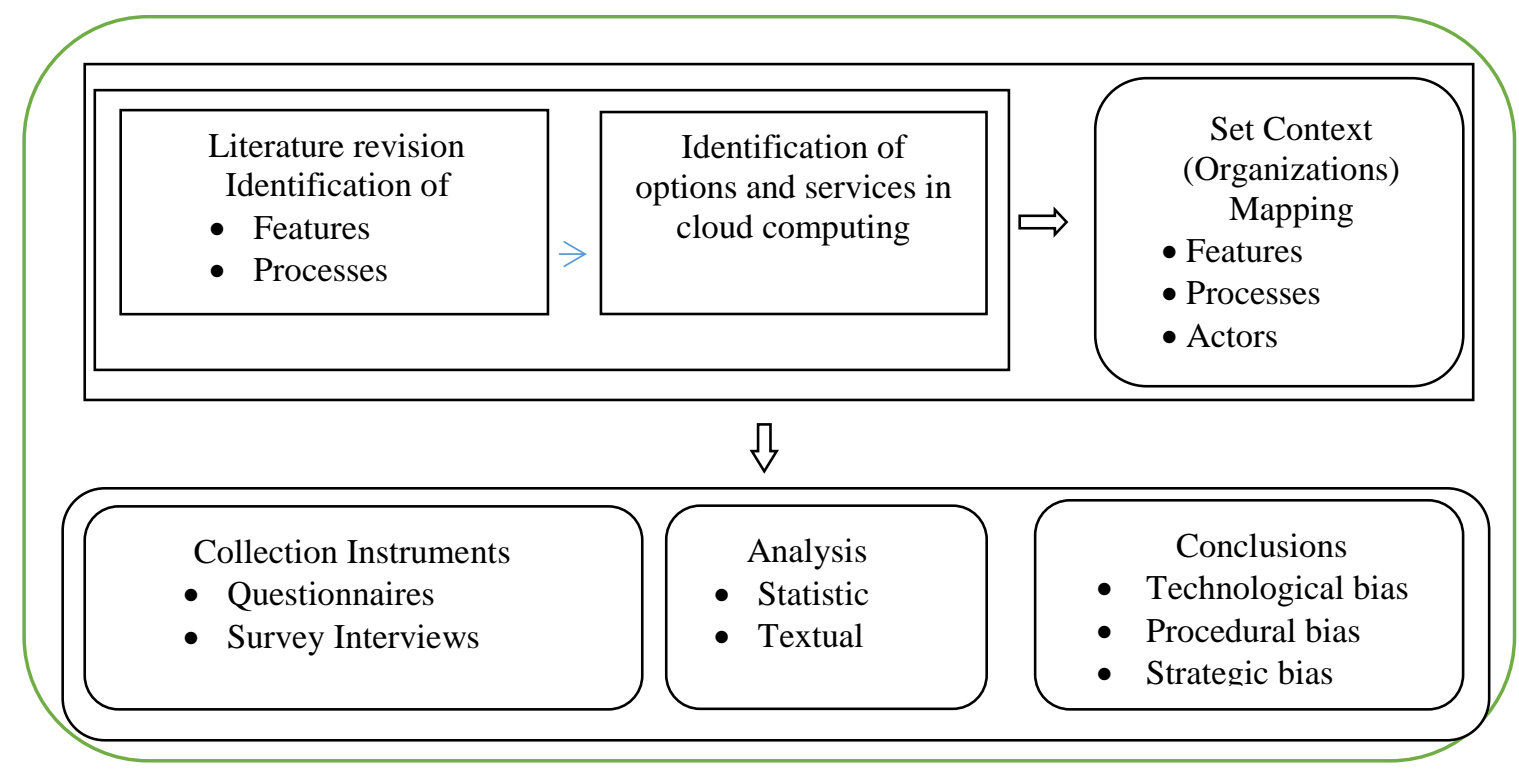

Source: own elaboration. 


\subsection{Application of questionnaires}

The questionnaire, composed of closed questions, was built based on the detailing, in variables, of the objectives pursued, especially with regard to the use characteristics and knowledge of the cloud computing technique and its potential application in public management actions. The issues then followed a logical sequence, ranging from the notion of what was estimated by cloud computing to actions to control the ICT infrastructure.

After a pre-test with a group of ICT specialists, the questionnaire was hosted on the Qualtrics ${ }^{\circledR}$ platform and a link for access was distributed to 168 employees identified as analysts of the state IT companies of the cities of Curitiba (CELEPAR) and Porto Alegre (PROCERGS). The questionnaire was exposed for 40 days and contacts with people close to both cities were made in order to achieve an increase in the response rate.

The choice of these companies was made because it was intended to investigate the municipal scope of ICT of each one of the chosen cities. Therefore, for the two reasons the option was communicated before: there would be cultural proximity between the respondents of the questionnaire and those interviewed; There would be no risk of double infirmity within the chosen units of analysis.

In addition, the public formed by ICT managers and users, selected by invitation, that directed to the link to the instrument, had been encouraged to respond to the instrument if and only if they declared themselves - 1st and 2nd issue of the survey - already know or use computing In the cloud in their tasks and that they knew of the pretension of use of the technology in the activities developed in the companies of TIC of the state and the municipality. The answers were given faith!

The instruments obtained and taxed of valid, in quantitative equal to 100 , were processed considering the provided interface, being validated the calculation techniques of analysis through the simple descriptive statistics. The visualization of the results was manifested in the form of tables and graphs.

\subsection{Survey Interviews}

The second form of collection was based on survey interviews, whose spectrum focused on topics under study and questions to deepen understanding, especially in the public sphere of the two cities icons. The reason for the selection of heroes was due to the common sense that there are organs that are always in the vanguard of appropriation, and that there are cities in the country that have become famous for practicing immediately, in the public sphere, technological innovations such as cloud computing.

With this profile the choice fell on the leaders of the cities of Curitiba and Porto Alegre.

About the former, it is always spoken of as an example of innovations and appropriation of technologies for the public thing. The city has avant-garde tradition in urban planning, quality of life and preservation of nature. Also in areas of information technology, dates from the late 1970s, news of early adaptations and uses of social or popular computing (PAIVA, 2007). 
From the second they provide evidence of strong popular participation, with examples of participatory democracy, anchored in technological innovation. This fact of wide popular repercussion placed over a long period the city as a decoy of scholars even of electronic coalitions (PERUZZO, 2006).

Thus, because they represent points of interest to be scrutinized and already have a first impression collected, it was decided to listen to managers of these cities, which were reached locally, at their workplaces, for tapping into recorded interviews, each lasting Average of 30 minutes.

The script covered eleven questions divided into two big blocks:

- The first with administrative connotation - three blocks of three questions each, about the technological, procedural and strategic bias of the use of cloud computing in management activities that envisage the citizen as the recipient of the service;

- The second with political connotation - anchored in two questions about the future and continuity of public management supported by the motion of services based on cloud computing, to the management routines more directed to participation and popular democracy.

The consigned data were subjected to a qualitative treatment in order to lend them meaning, context and relevance, through a basic textual analysis.

\subsection{Data analysis}

To the data from the questionnaires were applied trivial statistical treatments with the help of Excel ${ }^{\circledR}$ software, from which data grouping measures were generated, shown in simple graphs, with the purpose of glimpsing the regularities of response in the collection.

The great guideline of this stage was to obtain conditions to listen to knowledge and receptivity of cloud computing in the routines and widely consecrated actions of the administration, even in public hosts, around processes, functions and strategies as it teaches Daft (2008).

On the other hand, the qualitative data procedure, from the interviews, was inspired by the grounded theory analysis proposal, consolidated by Strauss \& Corbin (1998), observing the variants listed below, based on the ideas of Flick (2009).

Systematic coding sought to reduce the various passages of the codes to the objectives or questions themselves, seeking to describe the aspects found in the design presented in the data analysis model, shown in figure 2 . This reduction, verified during all coding phases, was based on record units - the question -; Context unit - the response - and categories - the variants within the responses.

This process of data analysis led us to conceptualize in the structure of analysis: naming a phenomenon - the main convergent factor in the answers - which abstracts events, objects, actions and interactions - elements that assumed a connotative space in the model (cause, context and strategies). This effort converges to the illustration outlined in figure 2. 
Figure 2. General model for data analysis of deepening interviews.

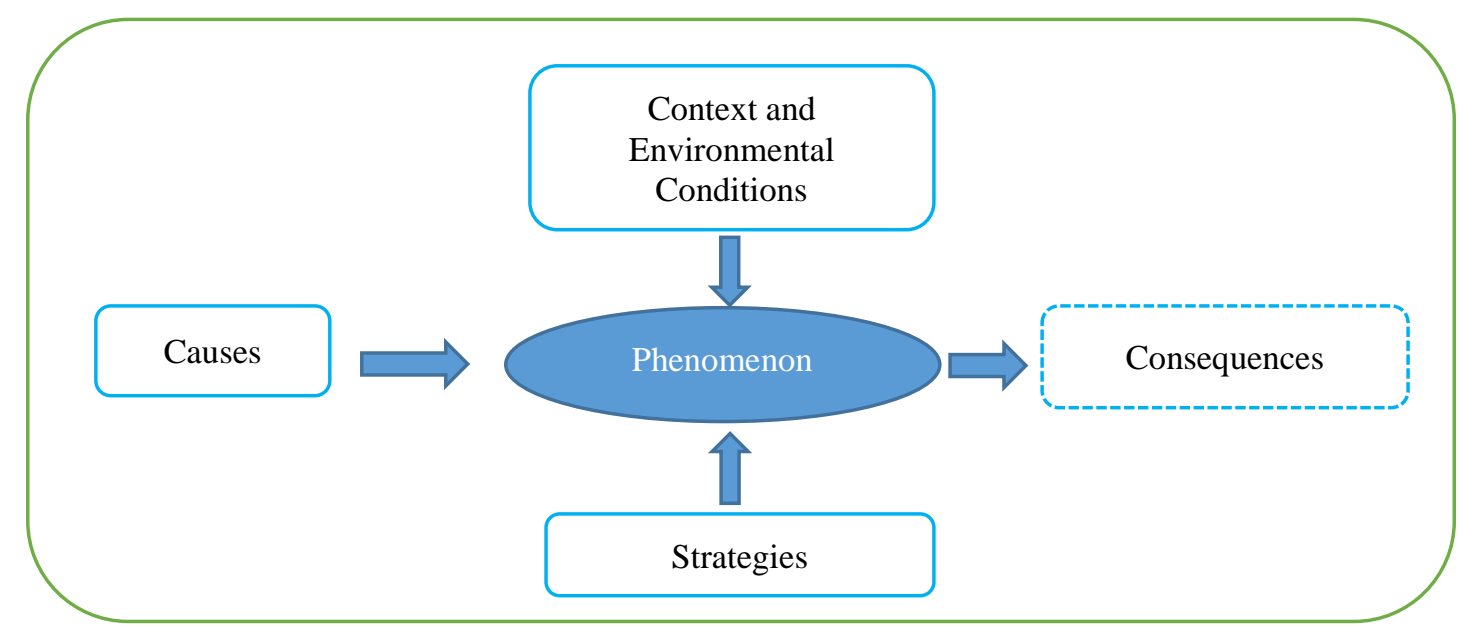

Source: Inspired by Flick (2009).

The thematic content analysis (BARDIN, 1977) was applied to the ears to obtain the open coding. The context units served to generate the intervening causes, strategies and conditions, which brought together categories that converged to the phenomenon - aggregating dimension of the analysis. The phenomenon, in turn, conditioned the consequences conjectures of the interpretation of the use of cloud computing in that phenomenon. The categories found, the fruits of the codification, were, in turn, groupings in a lower level of abstraction, reducing and grouping the mentioned concepts even more.

\section{RESULTS AND DISCUSSION}

The analysis undertaken here favors the general interpretation of the results of the survey carried out in this research. Thus it comprises two well-defined blocks: the so-called quantitative analysis and the analysis of the phenomenon cloud computing in its dimensions.

\subsection{Analysis of survey questionnaires}

The first questions sought to clarify the notion of the respondents about cloud computing technology as an item of knowledge and use or as a presumed possibility of use in the transactions of public management. It was confirmed that $89 \%$ of the respondents already knew the technology, either by news, or by notion of market, or by having already had contact. This data ratified the tendency to affirm Martinez (2010) regarding the persuasive strength linked to this technology. In addition, in detail, respondents perceived cloud computing technology as a trend of migrating from centralized to decentralized computing.

A crucial interest of the research was to know what the actual use of this technology in the public sphere would be at this time. In this regard, according to the respondents, $29 \%$ on average claimed to be enjoying some variant of this technology. Although it is a high percentage, almost $1 / 3$, it was realized that there was some confusion between the notion of using the cloud with other variants such as access to portals and collection of government information. 
Of the almost two-thirds who said they still did not see the use, $47 \%$ showed the possibility of implementing it gradually in the governmental actions, $18 \%$ affirmed that they believe that the cloud computing will be implemented, but not now; And 6\% are convinced that this system will never be implemented.

Thus, from what we can see from the results, cloud computing appears to be a convenient technology to be deployed, where it is still not recognized and there is a certain temporal expectation that this will happen, almost inexorably (94\%). The revalued spectrum in this detail is shown in figure 3.

Figure 3. Respondents' expectations regarding the use of cloud computing in actions.

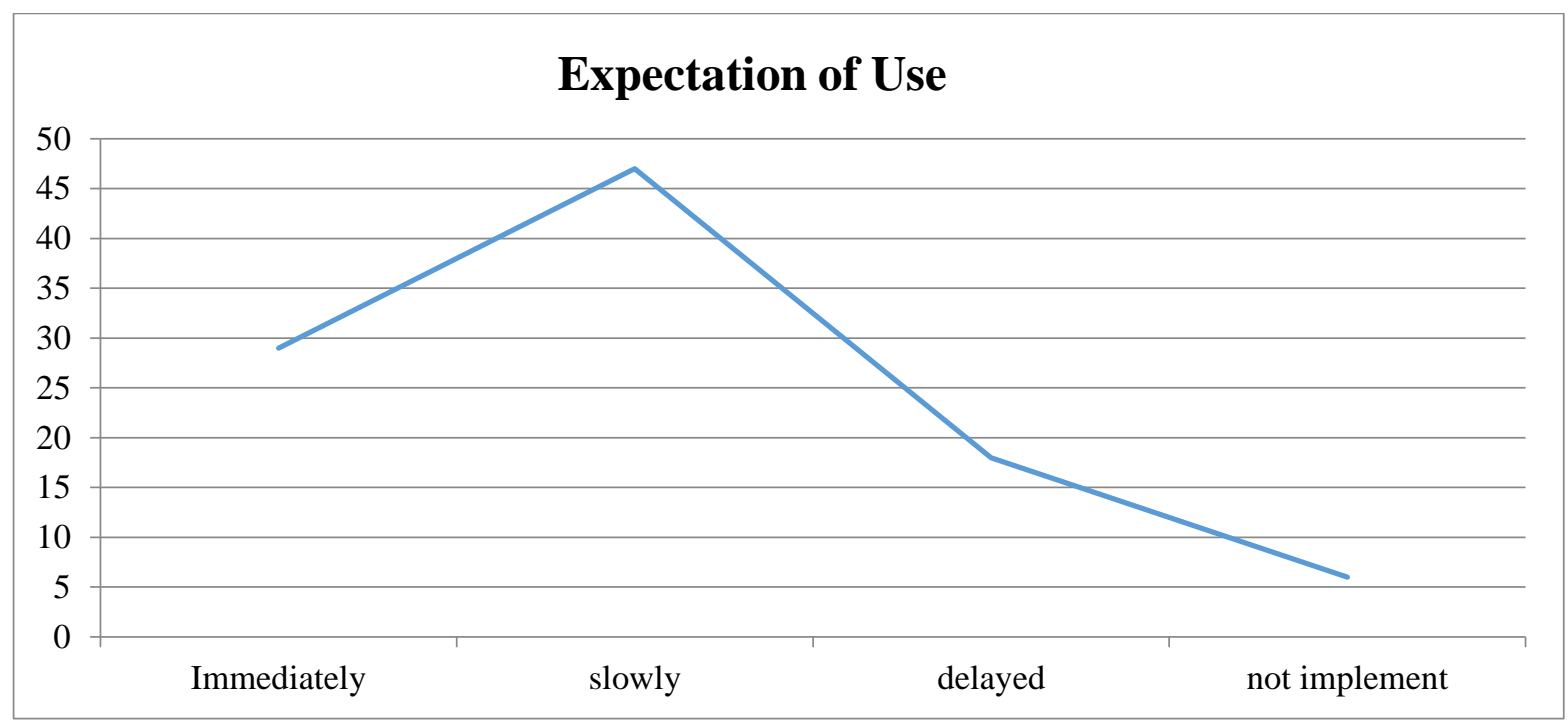

Source: survey data.

Also sought to find out what motivations would lead a public organization to opt for the use of the cloud service. The answers indicate that in people's view, such ventures seek productivity and efficiency, thinking less of costs (though they think). The key construct chosen to cover these relations was called motivation for the choice of technology and is globally depicted in figure 4, with the social and current use of technology as the detonator.

Figure 4 shows that, although there is a general emphasis on costs, this does not appear to be the main managerial motivation, a factor that can be credited to productivity, followed by efficiency. Two concerns predominated in the other category: transparency and accessibility, which became key items for investigation in the second stage. 
Figure 4. Motivations for using the cloud computing service.

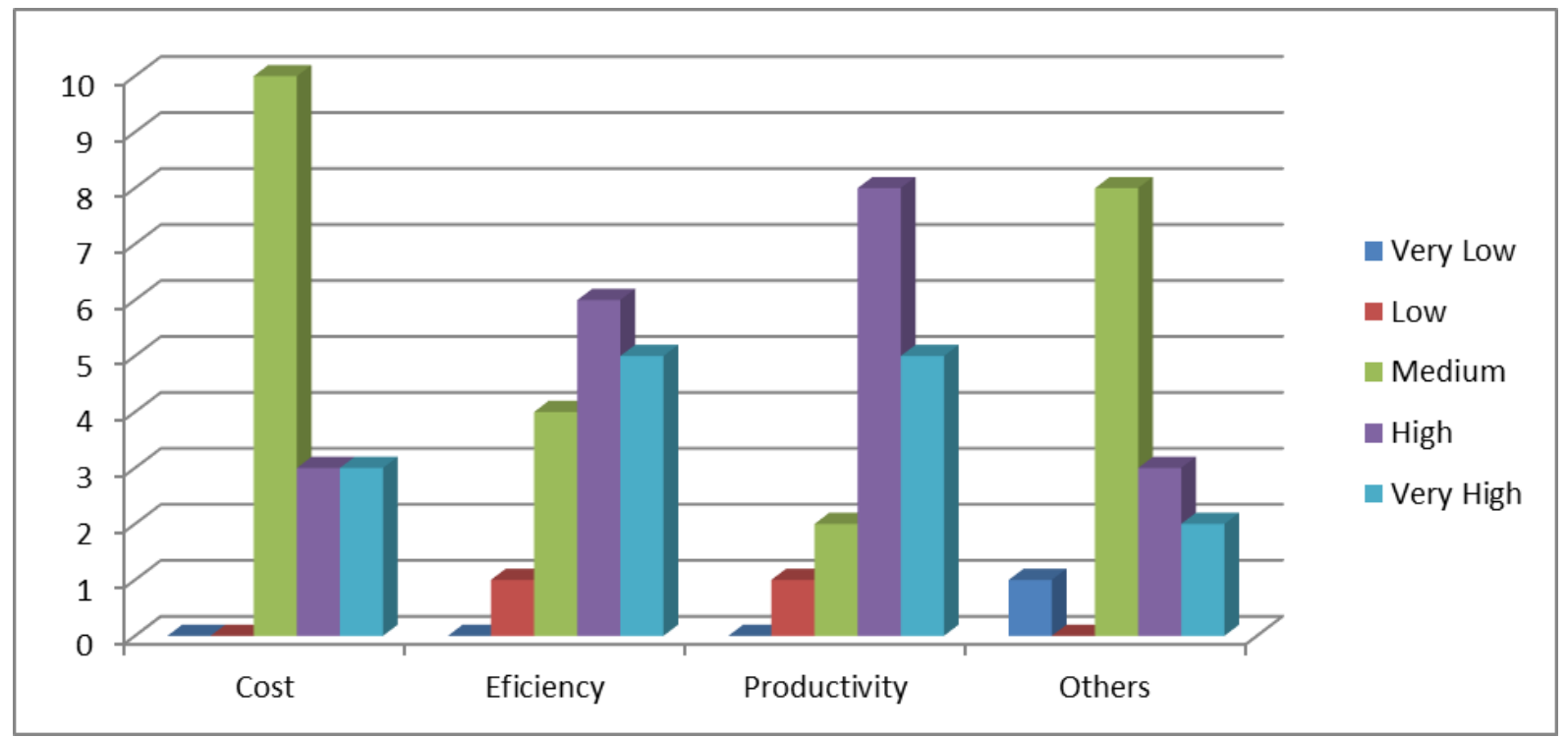

Source: survey data.

Then, when looking to minimize in totum which areas would be likely to have greater relative importance for operationalization and eventual migration to cloud computing, a general lack of definition was very well represented in figure 5, due to the almost unanimity of the intermediate option for all the alternatives of areas cited.

It is to be speculated that none of the functions indicated has any prominence regarding cloud visualization, which is a picturesque fact. Nonetheless, some results have a revealing point.

Figure 5. Functional areas and their prospects of being migrated to cloud services.

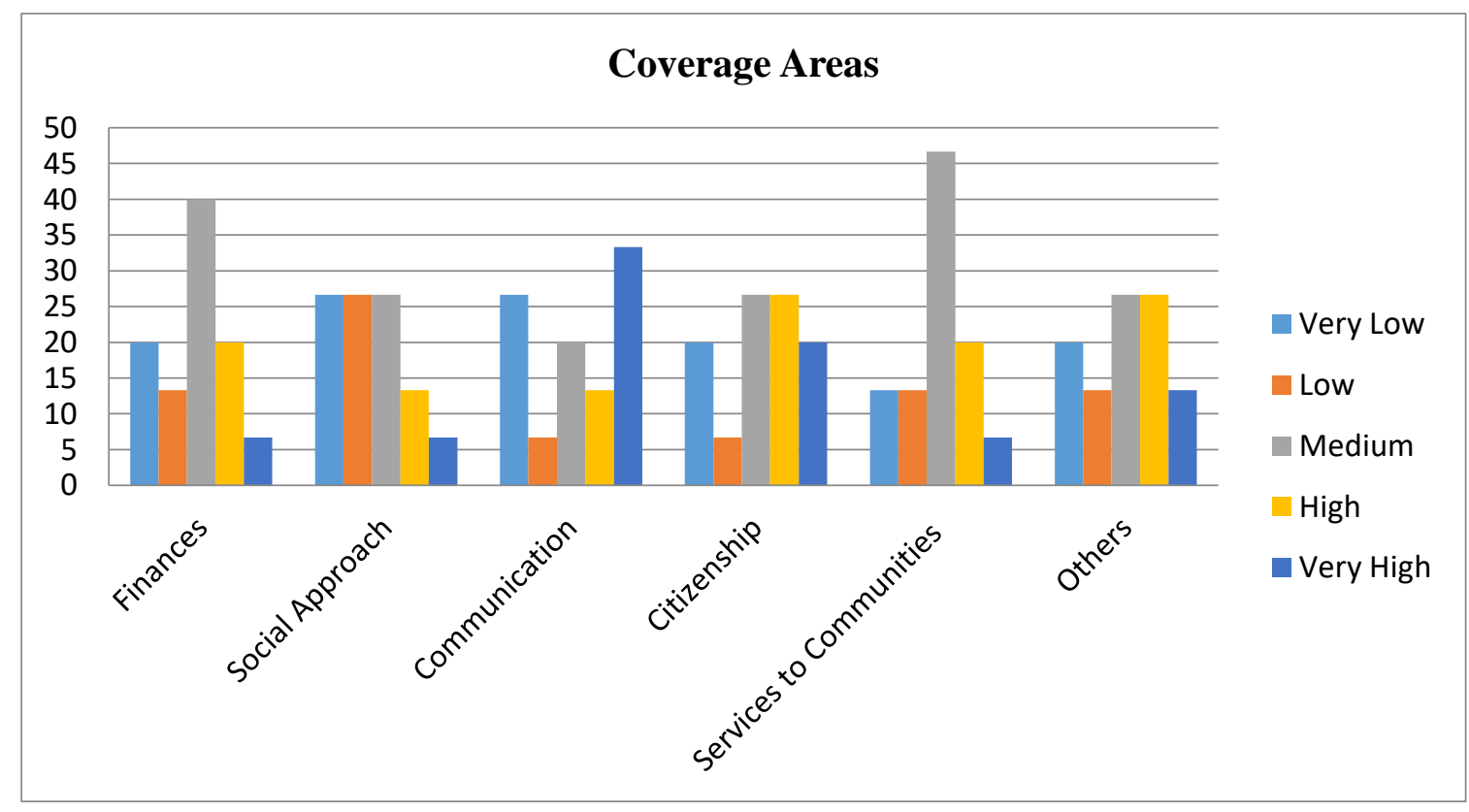

Source: survey data. 
For example, the scope of the finance function with a high perspective of being moderately adaptable to the cloud certainly carries with it a certain involvement with the issue of transparency of information; an analysis that with some parsimony can be extended to the service delivery function and its understanding as e-government actions, especially those mandated.

Notably social approach is action whose disbelief of implementation as a cloud service is high, about $75 \%$ of opinion; in the same way that the communication function stood out, though not as much as expected, the only one being that the total agreement with the possibility of being in the cloud was the winner.

Finally, actions related to citizenship obtained the most indefinite profile among those named, perhaps because of their possibility of association with social networks. In the other option there was a sprinkling of quotations and the most outstanding of the options was the possibility of formulating proposals for bills.

Regarding the risk conditions created for a possible migration of the service traditionally offered in government-based ICT companies, raised in the question as barriers to migration, the references in figure 6 were listed.

Figure 6. Influence levels of factors that inhibit migration to the cloud

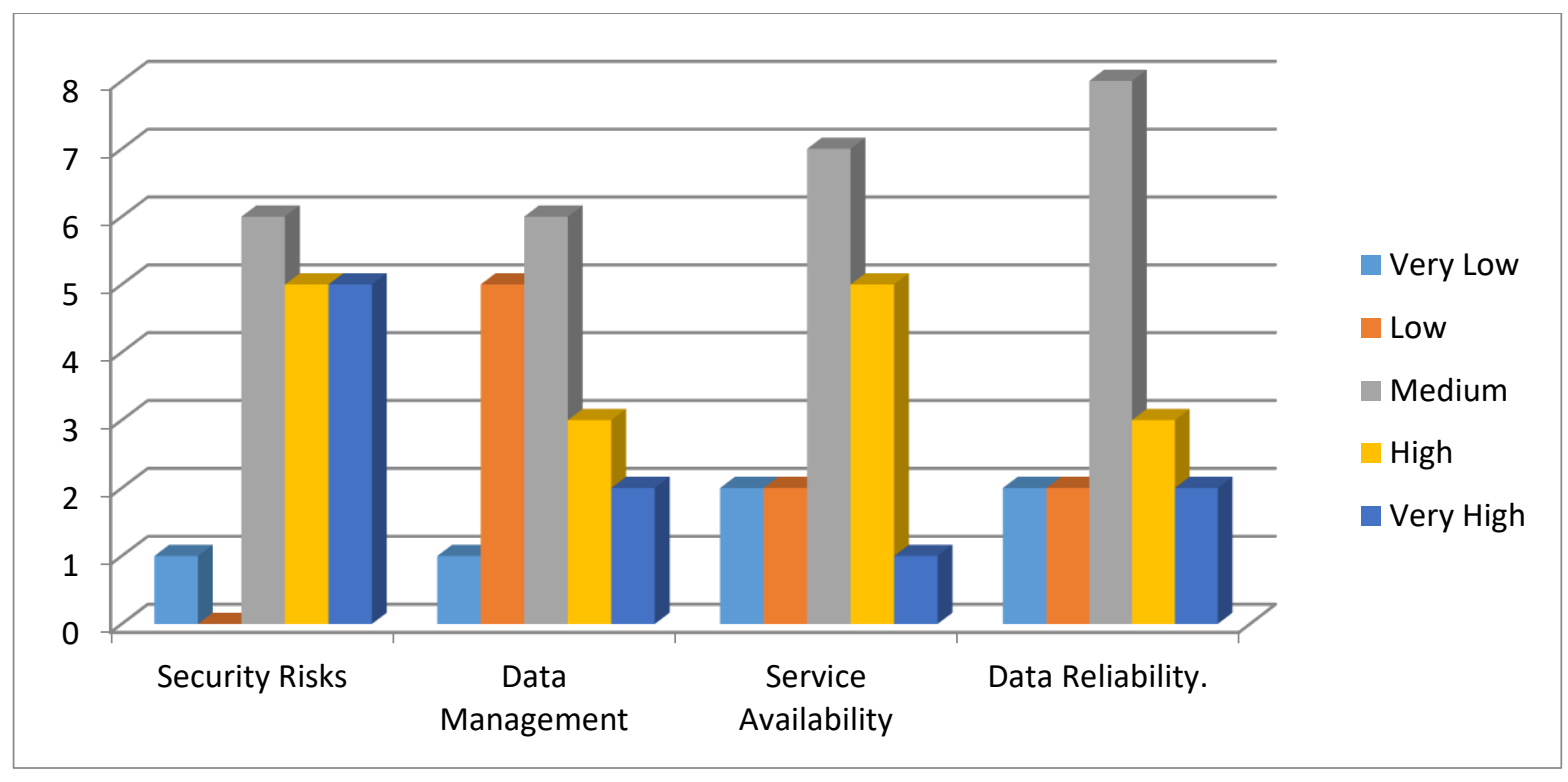

Source: survey data.

Uncovering their compencization, there are more surprises than confirmations, especially if the result is mirrored in entities of the private initiative as stated in Veras (2012). At the outset, it was found that the cautious intermediate position predicted in the scale was the most pointed out by the respondents in all alternatives. 
It was also pointed out that, except for the alternative data management, the most negative perception perceptions (in the case of the interpretation of the scale in this question corresponded to the area of agreement with the assertive) were the majority; That is, the recognition that the barriers are still stronger than the incentives to migration in three four variants were predominant.

When the alternatives pointed out by the respondents were decisive (there was an effective position), the most exacerbated perceptions were the risks to the security and computational structure and availability (36\%) and secondly Reliability (28\%). In fact, it was expected that availability would be much more considered in this case.

As for the perception regarding data management, the strong miscegenation between the concept of cloud computing and data centers, especially on the basis of e-gov (LAIA et al., 2011), may justify the slight anti-argumentative advantage that this alternative has reached, so as not to be seen as an effective barrier to migrating to the cloud service.

Next, we sought to verify what the franchise would be and the nature of the information that could be expanded to the cloud.

In this regard, it was gathered that the managers of the actions - secretaries or the like should be the most franchised in terms of access and, understandably, the respondents intuited that the information to be made available would have to be massively operational, Monitoring their activities need. This information when crossed with the fears previously revealed, magnify the issue of access security and data as an effective obstacle to the migration of information.

Thus, combining the two issues, it was realized that access to this information will be granted to all those who are part of the community, with the appropriate restrictions linked to the structure of governmental secrecy, as Daft (2008) teaches, while the stored information Must be based on the operational content, which have a low strategic value, are presented in greater quantity, but guarantee a broad knowledge of the management activities.

Completing the examination of the closed data, and with its already identified complex, it was started to deepen the use of this same platform in the level of the provision of social computing by the governmental sphere (SACCOL \& REINHARD, 2007).

From there was carried out the attack on the heroes of the chosen cities.

\subsection{The qualitative step of the survey}

Curitiba city is considered almost unanimously a pole of innovation and advances in government informatics. Always attentive to the news and its implementation has the label of smart city. In that city, 5 high-ranking leaders of public companies were interviewed at the end of August 2015.

Respondents spoke at their workplaces and agreed to respond in a free format to the questions as they were being formulated, but with freedom for ramblings. 
At first he tried to find out what the interviewees' concept was about cloud computing. It had been rescued that within the standardized responses of phase 1, there was some confusion between cloud usage and cloud storage. It was no different here.

Most interviewees listed that the concept is in fact diffuse and represents "an improvement, an evolution of transactional computation" (Interviewee PR01), which is in line with the perspective of Turban \& Volonino (2013), which tax cloud computing As an advance of decentralized computing.

Interviewee PR04 pointed out in a clear allusion to social networks, which is facing an evolution of access and storage, referring to good communication channels: "I wonder if it is not a link that joins another link And is forming a pool that only needs management "(Interviewee PR04).

Strictly speaking, these technical aspects in PR03's opinion make it easier to "manage demands and balance large volumes in a shared way and this increases the capacity of available resources, storage capacity and service delivery to the community."

According to the high-ranking curitibano, the great advantage of this option of computing "is that who uses can have access to information without knowing where it is" (Interviewee PR02).

Thus, it was generally perceived a good perspective of understanding the concept for work, but it was also detected that it is still ingrained in storage, which to a certain degree ratifies the lack of conformity highlighted in the first stage.

In closing, the two experts from Rio Grande do Sul ratified this disagreement when they stated that in their visions, cloud computing was only recognized as data centers to gather information available to society.

The arrangement of the mentions here annotated to this question allows to sketch in respect to the model of analysis recommended the following arrangement.

Figure 7. View of the phenomenon cloud computing from the perspective of the interviewees.

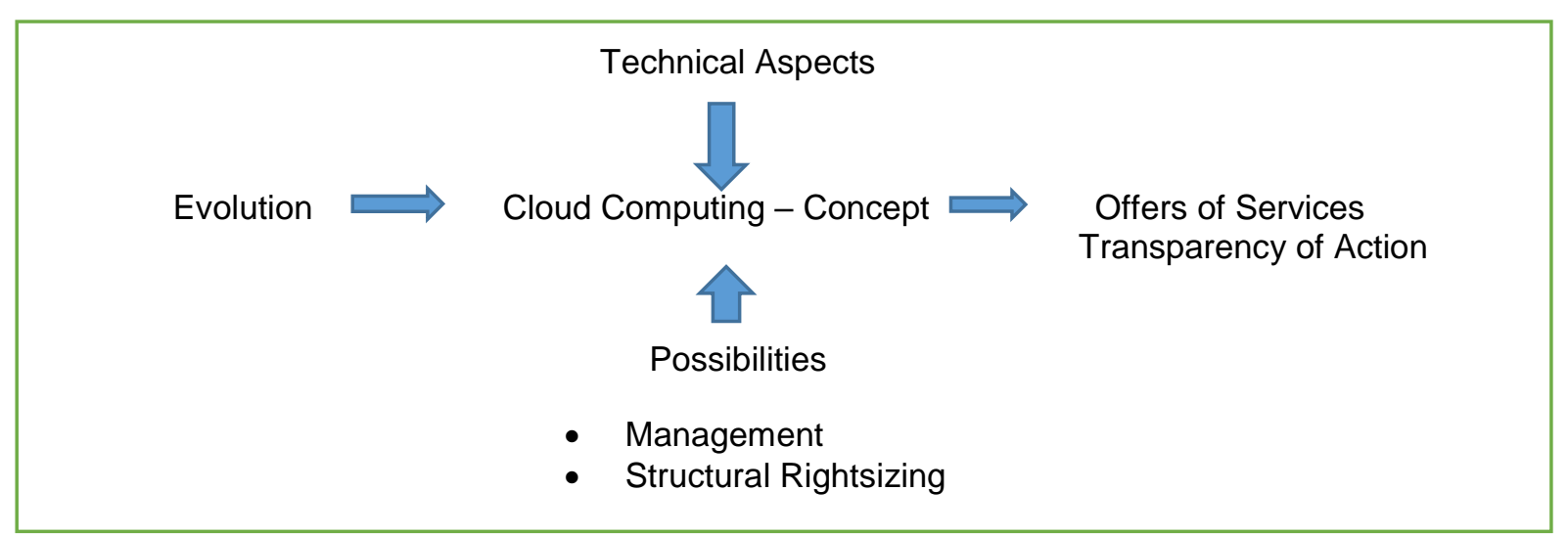

Source: Research analysis. 
The second question argued whether organizations would be ready to use cloud computing, how they conceive, and how to establish relations with citizens. Here there was a supposed convergence of institutional political profile in Curitiba, because it emerged strongly the category of "being ready to respond to the wishes of society" (Interviewee PR04).

In this regard, Interviewee PR02 summed up the spirit of facing this need with two illustrations: the modernization of the relationship with the community and the provision of fast and quality services; Both mapped in the excerpt "the people are modern in their daily lives and can not count on an archaic service while providing government activities" (Interviewee PR02).

In Porto Alegre, the need for and predisposition to the adoption of cloud computing technology was rewarded by the community service delivery aspects, be it "by a greater proliferation of access channels, including media and social computing points" (Interviewee RS01), Or the construction of "a necessary architecture of services that makes the citizen coparticipant in municipal management, with the power to influence it" (Interviewee RS02).

The strongest notion of this questioning leads to the realization that the management of these cities is compelled to migrate to cloud computing, due to the need to offer services, and this is because management itself has expanded access channels and management processes in which The community relations are based, and must obey an architecture that allows generating services.

Because of this prominence that was collected in the field about process as a service (PaaS), it was pertinent the curiosities to investigate how the processes that are projected for cloud implementation are focused on these model cities.

Most of the ears, especially those most in the ICT area, said that it is of fundamental importance to understand, describe and model the processes supported by information technology, regardless of whether they are thought of as a service.

"The network of connections to be established in a process is vital to demand a very high set of links between demand and supply of services," said the interviewee RS01, because after all there is no exact notion of the user profile "is not known exactly Who is using it or how they are using it, "added the RS02 Interviewee. It will be very important to design models that are standardized and open. Interviewee PR05 went further, characterizing the centrality of the state in modeling:

The government is in the middle of all processes; so modeling in their links must be a priority, leading to a chain solution, where the governing body is the brain, the center of activities. (Interviewee PR05).

However, the difficulty pointed out by both Curitiba and Portalegre people goes back to the fact that nowadays, the public sector does not offer the management of these connections to the satisfaction. The model, when it exists, is static and does not offer an architecture that is manageable at any point, as it requires a cloud process with rules and parameters defined and flexible in a range of possibilities (VOUK, 2008). 
This imperfection, in Curitiba, gave rise to a new secretariat to manage technology contracts and define which are critical processes. It will be up to this body to discuss within the modeling what tunes to criticality and speed to implementation and this will certainly accelerate the prediction that less critical processes will be scalable to the cloud.

The critical processes are not consolidated at the level of this new secretariat; That is, we do not yet have a vision of the City Hall and as a consequence there is little glimpse into the vision of society. (Interviewee PR03).

However, there remains the problem of prioritization of which processes can be directly developed for the cloud, eg "through hackathom partnerships or marathons." (PR04 interview).

Figure 8. Process as a phenomenon for cloud computing in the interviewees' view.

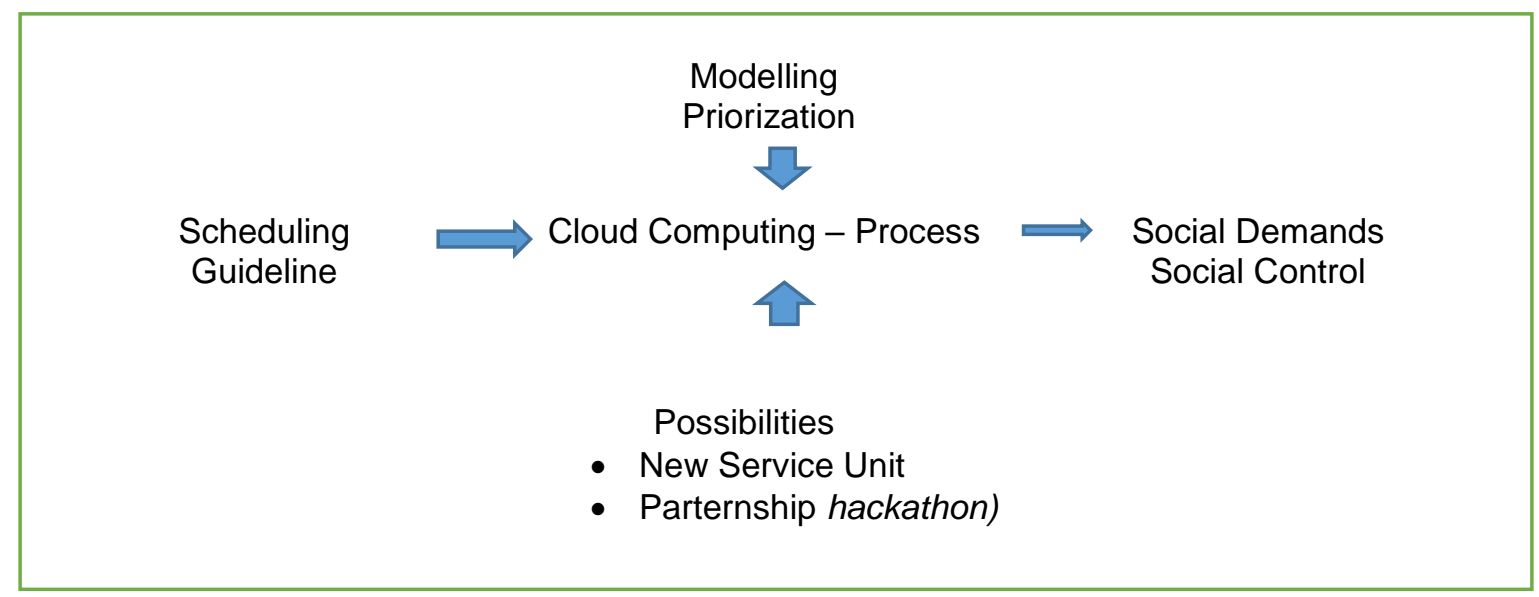

Source: Research Analysis.

Finally, it was verified that if part of the internal operation is well done, the information for external demands does not yet exist and, therefore, would be more difficult to contribute in the cloud, and these deals lead to the mimesis of the phenomenon relativized by processes.

The next question sought to associate the known types and modalities of cloud computing with the interviewees' imagery. The intention was to seek a global perception of how cloud computing was approaching, bringing the experimentation closer to the conceptual one. 
Figure 9. Perspectives on the modalities of cloud computing (Paraná view).

\begin{tabular}{ll}
\hline Person & Perspective \\
\hline Interviewer PR01 & $\begin{array}{l}\text { "There's no reason to think about cloud computing; I'm thinking of all my } \\
\text { packages and applications, which depend on the priority set of the City Hall " }\end{array}$ \\
\hline Interviewer PR02 & $\begin{array}{l}\text { "There's no reason to think about cloud computing. As an example I show the } \\
\text { mobility application that monitors in real time the bus fleet of Curitiba that } \\
\text { appeared spontaneously" }\end{array}$ \\
\hline Interviewer PR03 & $\begin{array}{l}\text { "It's fair to think of data center outsourcing and contract. Hence one may be in } \\
\text { the cloud and this be transparent to me " }\end{array}$ \\
\hline Interviewer PR04 & "Attend another data center, database as a service" \\
\hline Interviewer PR05 & $\begin{array}{l}\text { "Layered architecture with a range of services. This is more for software as a } \\
\text { service, although I see more as " }\end{array}$ \\
\hline
\end{tabular}

Source: survey data.

In Porto Alegre no explicit mention was made of the modalities explicitly, although it can be said that the DbaaS modality around storage was preferred.

Barriers and difficulties were also detected in the implementation of the cloud computing service, generally aimed at security and transparency in the eyes of the hearing.

Knowing that Curitiba and Porto Alegre have histories of long periods of the same governments (LAIA et al., 2011), but still have presented some dismantling of municipal management platforms, it became a political issue to interweave aspects of computing in Cloud and e-gov.

Thus, it was asked if the use of technologies such as cloud computing, modeling processes and establishing technology-based and service-based platforms of processes, would not be configured as a bulwark to avoid these level discontinuities on administrative management.

Emphasized PR02 Interviewee, the one who performs first municipal function, affirmed that yes, but it was unique affirmation limitadora. The other opinions attested a good possibility, but unanimously affirmed that in politics nothing is definitive.

The final questions of the interviews aimed to look for the relationship, if it were to be, between cloud computing technology and intelligence, as the literature says that the use of cloud computing is a sine qua non for the implementation of intelligent, In ICT and in virtual processes (OVERBY, 2008).

The interviewees in Curitiba bet on a mapping of activities converted into services, processes implemented in the cloud, which will completely change the face of the government that wants to implement.

In this case the intelligence of the government will also be another. If you can do the analysis of the facts, the movements and from this mapping allied to the cloud, the platform of 
anticipation of the government will be completely different. (Interviewee PR01).

Respondent RS02 reported that anticipating demands would also make it more flexible to stipulate applications, indicating that "such demand for applications grows as the subject matters and has agglutinating profile in the use of sites."

This greater closeness and greater prospect of intelligence improves a priori the relationship of government with the citizen. In fact, as the PR05 interviewer stated: "from the moment I have the concrete clues, I use standardized intelligence to reap more fruit."

Figure 10. Intelligence as a phenomenon related to cloud computing from field point of view.

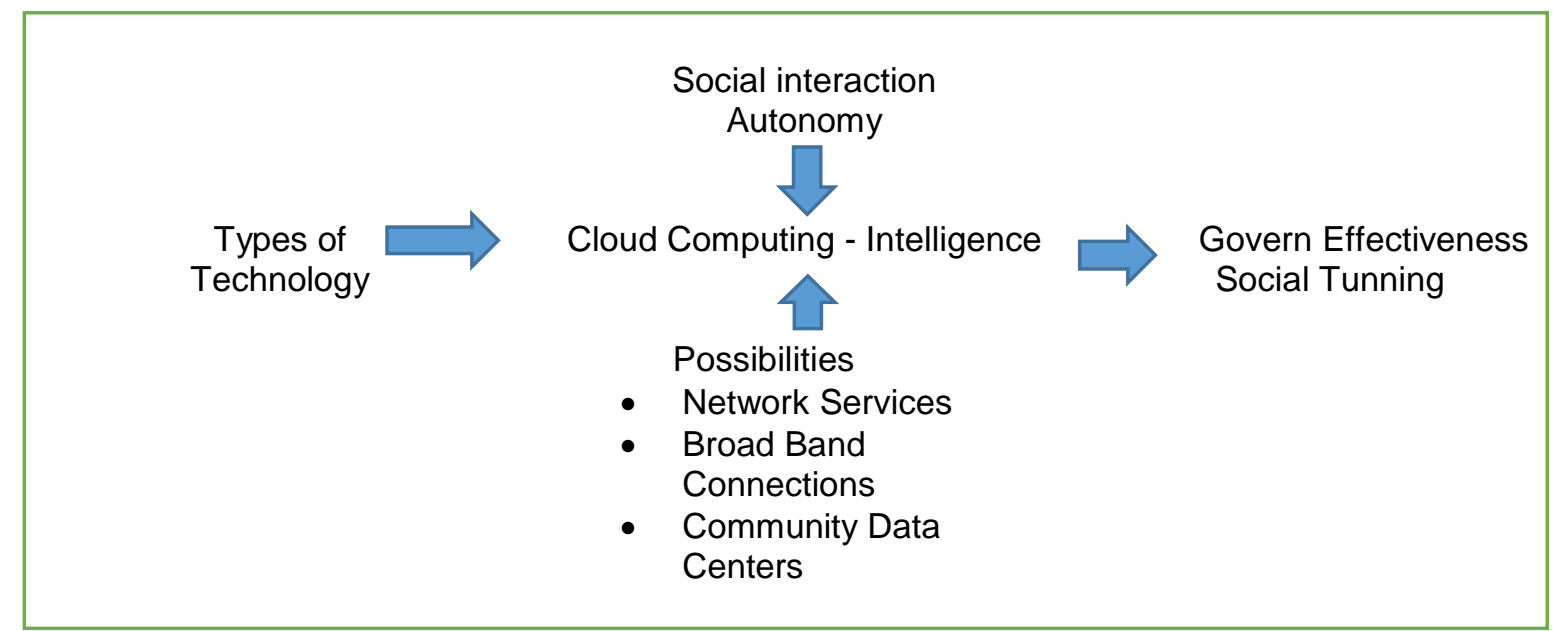

Source: survey data.

\section{SUMMARY AND CONCLUSION}

The objective of this research was to understand the perception of the phenomenon of cloud computing in the organizational context and to highlight indicators of its use and directions in the functioning of organizations that operate public management.

In order to do so, it made an adjusted inventory of the conceptual perception of technology and placed it within the scope of virtuality, equated it with a virtual process, which if it existed would be worked on e-gov platforms.

In order to discuss the idea in the conceptual scope delineated, it was decided to seek to understand how the inclusion of cloud computing in the routine of municipal management would be given. 
The cities of Curitiba and Porto Alegre, metropolises that traditionally are associated with quality of life, social participation, political awareness, urbanity and constant technological innovation in municipal management processes were chosen for this purpose.

Once the cities were selected, in order to have an adequate view of the managers' vision, a two-step survey was chosen. To do so, a standard questionnaire with closed questions was designed to inventory the global perception about cloud computing in information technology companies in the states whose capital cities had been chosen.

With the help of partners from these cities, an electronic list of collaborators was obtained and for these a link was sent to the digital questionnaire.

From the application of the questionnaire it was verified that the knowledge about the cloud computing is ample, but diffuse in particular by the confusion made with the notion of data center.

There have been perceived obstacles to an effective migration of the classic administrative actions of these types of social organizations, even more because they have strong political components. The main obstacles addressed the security risk and poor compliance of processes to new virtual needs.

It was perceived some forms of organization for cloud computing, but in general, and as the most present, the idea was fixed around the outsourcing of data storage (DBaaS). Also detected in a still very incipient way the possibility of processalization (PaaS), generating the virtual processes for the administration.

We sought complementarity to investigate the meaning of cloud computing technology directly with leaders of the management of the two municipalities. The finding was no different.

Cloud computing is also known, but it is very closely related to DBaaS in the data center figure, where you want to store comprehensive, detailed data that allows for e-government in advance.

Hence the concern is still very focused on: qualification of standardized services, proliferation of channels of access to society, establishment of partnerships and acts of transparency in management.

Finally, it was investigated what would be the contribution of technologies such as cloud computing to the effective role of social computing. In this front, it was verified that the migration of processes to the cloud would be a bulwark to guarantee the continuity of administrative process, even if at first massive for operational processes, and that technology is a fundamental condition for achieving smart and profitable computing at the Citizens, whether in intelligent cities or in intelligent organizations. 


\section{REFERENCES}

AGNES,D.P. (2007). A virtualização de processos em organizações públicas: um estudo de caso na Polícia Civil do Estado do Rio Grande do Sul. UFRGS. Porto Alegre.

AMORIM , A. N. G. F.(2007). Exportação de Software via Internet: Um Modelo Para Pequenas Empresas Brasileiras Recife. Dissertação (Mestrado). UFPE.

BALDAN, R. et al. (2009). Gerenciamento de Processos de Negócios. São Paulo: Editora Érica.

BARDIN, L. (1977). Análise de conteúdo. Lisboa: Edições 70

BARBOSA, A. F. \& FARIA, F. I. de \& PINTO, S. L. (2004). Governo eletrônico: um modelo de referência para a sua implementação. (CATI), Anais... São Paulo: FGV/EAESP.

BHARDWAJ, S. (2010). Cloud Computing: a study of infraestructure as a service (IAAS). International Journal of Engineering and Information Technology. v. 2, n. 1. 2010.

BUYYA, R. ET AL. (2008). Market-Oriented Cloud Computing: Vision, Hype, and Reality for Delivering IT Services as Computing Utilities. The 10th IEEE International Conference on High Performance Computing and Communications. 2008.

BUYYA, R. BROBERG. GOSCINSKIVA, A. (2011). Cloud Computing: Principles and Paradigms. New Yors: John Wiley \& Sons. Chapert 1 DOI: 10.1002/9780470940105

CANO, C. B. \& BECKER, J. L. \& FREITAS, H. M. R. (2004). A organização virtual no Espaço Cibernético. Porto Alegre: UFRGS.

CARR, N. (2004). Does IT Matter? Information Technology and the Corrosion of Competitive Advantage. Book

CHOI, B. (2009). Taxonomy and Survey of Cloud Computing Systems. Fifth International Joint Conference on INC, IMS and IDC.

DAFT, R. (2008). Administração. 6ª Ed. São Paulo: Atlas.

DENNIS, A.R. (2003). The Adoption and use of GSS in Project Teams: toward more participative processes and outcomes, MIS Quarterly, v. 27, n. 2, p. 289-323.

DIKAIAKOS, M. \& PALLIS, G. \& KATSAROS, D. \& MEHRA, P. VAKALI, A. (2009) Cloud computing. IEEE publications.

DILLON, T. ET AL. (2010). Cloud Computing: Issues and Challenges. 24th IEEE International Conference on Advanced Information Networking and Applications.

FLICK. U. (2009). Introdução a Pesquisa Qualitativa. Porto Alegre: Artmed.

GARCIA, T. \& POMAR, C. \& HOESCHL, H. (2004). Democracy in the electronic government era. Juridical Intelligence and Systems Institute, v.146, p. 67-76, 2004.

GEORGES, M.R.R (2010). Modelagem dos processo de negócio e especificação de um sistema de controle da produção na indústria de auto-adesivos. JISTEM, Vol 7. N. 3 São Paulo.

GULLEDGE JR, T. R. \& SOMMER, R. A. (2002). Business process management: public sector implications. Business Process Management Journal, v.8, n.4, p. 364-376.

JAIN, L; \& BHARDWAJ, S. (2010). Enterprise Cloud Computing: Key Considerations for Adoption. International Journal of Engineering and IT. v. 2, n. 2, 2010.

KARTHIKEYAN, N. \& SUKANESH, R.(2012). Case Study on Software as a Service (SaaS) in India. European Journal of Scientific Research, v. 69, n. 3. p. 461-472. 
LAIA, M. M. et al. (2011). Electronic Government Policies in Brazil: Context, ICT Management and Outcomes. Revista Administração de Empresas. v. 51, n.1, p. 43-57.

LAUDON; K. LAUDON. (2011). Sistemas de informação gerencial. $7^{\mathrm{a}}$ ed. RJ: Prentice-Hall.

LÈVY, Pierre. (2010). Cibercultura. Editora 34.

LÖFSTEDT, U. (2005). E-government: Assessment of current research and some proposals for future directions. International Journal of Public Information Systems, v.1, p. 39-52.

LUCAS, H. (2009). Tecnologia da Informação e comércio eletrônico Rio de Janeiro: Campus.

MARCON JÚNIOR, Arlindo. et al. (2010). Aspectos de segurança e privacidade em ambientes de computação em nuvem. Fortaleza, 2010. Disponível em: http://www.insert.uece.br/sbseg2010/anais/minicurso_02.pdf Acesso em: 09/04/16.

MARTINEZ, Eduardo. (2011). Você sabe o que é SaaS, PaaS e IaaS? Disponível em:http://readwriteweb.com.br/voce-sabe-o-que-e-saas-paas-e-iaas/ Acesso em: 10/04/16.

NOOR, S. A. (2010). A Proposed Architecture of Cloud Computing for Education System in Bangladesh and the Impact on Current Education System. International Journal of Computer Science and Network Security. v. 10, n. 10.

NORTON, B SMITH, C. (1997). Understanding the virtual organization. New York: Ed. Baron.

OVERBY, E. Process Virtualization (2008). Theory and the Impact of Information Technology. Organization Science, v. 19, n. 2, p. 277-291, mar./abr.

OVERBY, E. \& KONSYNSKI, B. (2012) Process virtualization: a theme and theory for the information systems discipline. In: ACADEMY OF MANAGEMENT MEETING, 2008, Anaheim, CA, USA. Acesso em 20 jan. 2015.

PAIVA, Raquel. (2007). Para reinterpretar a comunicação comunitária In: PAIVA, Raquel (org). O retorno da comunidade. Rio de Janeiro: Mauad X. p. 133-148.

PEREIRA, L. C. B. (1997). Estratégia e estrutura para um novo Estado. Revista de Economia Política, v.17, n.3, p.24-38, 1997.

PERES, A. (2008). A importância da gestão de conhecimento nas empresas. 2008. Disponivel em www.vivencial.com.br Acesso em 12/04/2015.

PERUZZO, Cicília M.K. (2006). Mídia local e suas interfaces com a mídia comunitária no Brasil. Anuário Internacional de Comunicação Lusófona 2006. São Paulo: Intercom. p. 141-162.

RAWTANI, M. R. (2012). Achieving Knowledge Management Through Cloud Computing. 8th Convention PLANNER. 2012.

SACCOL, A. \& REINHARD, N. (2007). Tecnologias de informação móveis, sem fio e ubíquas: definições, estado-da-arte e oportunidades de pesquisa. Rev. adm. contemp. vol.11 no.4 Curitiba Oct./Dec.

SANCHEZ, O. A. (2003). O poder burocrático Lua Nova, n. 58, p. 89 - 119.

SELAMAT, M. H. ET AL. (2006). Knowledge management framework in a technology support environment. International Journal of Computer Science. v. 6, n. 8.

SILVEIRA, S. A. (2005). Inclusão Digital, software livre e globalização contra-hegemônica. Parcerias Estratégicas, n. 20

STAIR; R REYNOLDS, W. (2011). Princípios de sistemas de informação. $9^{\mathrm{a}}$ Ed. SP:: Thomson.

STRAUSS, A. \& CORBIN, J. M. (1998). Basics of Qualitative Research: Techniques and Procedures for Developing Grounded Theory. London: SAGE Publications. 
TURBAN, Efraim. \& VOLONINO, Linda. (2013). Tecnologia da informação para gestão: em busca do melhor desempenho estratégico e operacional. 8. ed. Porto Alegre: Bookman.

UNDERDAHL, Brian. (2008). BPM for dummies. New York: John Willey and Sons.

VERAS, M. (2012). Cloud Computing: nova arquitetura de TI. São Paulo: Brasport.

VOUK, M., A. (2008). Cloud Computing - Issues, Research and Implementations. Journal of Computing and Information Technology - CIT. v. 16, n. 4, 2008. p. 235-246.

WARSCHAUER, Mark. (2006). Tecnologia e inclusão social: a exclusão digital em debate. São Paulo: Editora Senac, 2006.

WESKE, M. (2007). Business Process Management. New York: Springer.

WIGAND, R. T. (1997). Electronic Commerce: Definition, Theory, and Context. Author: Source: The Information Society, Volume 13, Number 1, 1 March. 